\title{
Upaya Empowerment Community Untuk Pencegahan Covid 19 Melalui PHBS Bersama Pengurus PKK di Kelurahan Johar Baru
}

\author{
Erialdy $^{1^{*}}$, Adji Widodo ${ }^{2}$ \\ ${ }^{1}$ Universitas Islam Syekh-Yusuf Tangerang Indonesia \\ 2Universitas Pamulang \\ *e-mail : erialdy@unis.ac.id
}

\begin{abstract}
The reason for this community service movement is to reduce the risk and prevent the transmission of COVID-19, which is a viral infection whose spread is massive. Some of the ways that should be possible, one of which is the application of Perfect and Healthy Living Behavior (PHBS), by washing hands using hand sanitizers and wearing masks. The method used in this community service activity is to look at the PKK cadres at the kelurahan level to the $R W$ level, it is also easy to reach with community leaders to facilitate activities. through webinars, the movement to wash hands using hand sanitizers and the use of masks can achieve the expected goals, this can be seen from the expansion in knowledge and public awareness to implement them. As a result, PKK cadres are able to become social agents in implementing clean and healthy living behaviors in their surrounding communities, by following up and monitoring the surrounding residents through partnerships by developing village officials.
\end{abstract}

Keywords: Empowerment Community, PHBS, PKK

\begin{abstract}
Abstrak
Alasan dilaksanakannya kegiatan pengabdian masyarakat ini adalah untuk mengurangi resiko dan mencegah penularan COVID-19, yaitu infeksi virus yang penyebarannya bersifat masif. Beberapa cara bisa dilakukan salah satunya dengan penerapan Perilaku Hidup Bersih dan Sehat (PHBS), dengan mencuci tangan menggunakan hand sanitizer dan pemakaian masker. Metode yang digunakan dalam kegiatan pengabdian masyarakat ini yaitu bekerjasama dengan ibu-ibu Kader PKK tingkat Kelurahan sampai dengan tingkat Rukun Warga (RW), juga bekerjasama dengan tokoh-tokoh masyarakat untuk kemudahan dalam mengkoordinasikan kegiatan. Kegiatan yang dilaksanakan berupa pembekalan manajemen pencegahan covid 19 melalui webinar, gerakan untuk mencuci tangan menggunakan hand sanitizer dan pemakaian masker dapat mencapai tujuan yang diharapkan, hal ini terlihat dari persentase peningkatan pengetahuan dan kesedaran masyarakat untuk melaksanakannya. Hasilnya, Kader PKK mampu menjadi agen sosial dalam menerapkan perilaku hidup bersih dan sehat di masyarakat sekitar mereka, dengan melakukan tindak lanjut dan monitoring kepada warga disekitarnya melalui kemitraan dengan segenap perangkat Kelurahan.
\end{abstract}

Kata kunci : Empowerment Community, PHBS, PKK

\section{PENDAHULUAN}

Organisasi Kesehatan Dunia (World Health Organization) sudah menetapkan virus corona menjadi pandemi pada Maret 2020. Status pandemi ataupun epidemi global menunjukkan kalau penyebaran Covid-19 berlangsung sangat cepat. Virus corona bisa menyebar dengan mudah serta menginfeksi siapapun tanpa pandang umur. Penularan virus ini lewat droplets ataupun tetesan cairan yang berasal dari batuk serta bersin, kontak individu semacam memegang serta berjabat tangan, memegang barang ataupun permukaan dengan virus di atasnya, setelah itu memegang mulut, hidung, ataupun mata saat sebelum cuci tangan. Perlindungan diri bisa dicoba dengan mencuci tangan dengan sabun ataupun hand sanitizer tiap berakhir melaksanakan kegiatan, memakai masker (Adryan Fristiohady, at al, 2021), pastikan juga jaga jarak fisik. Veils ought to be utilized as a component of an exhaustive 'Do everything!' approach including physical separating, 
keeping away from swarmed, shut and close-contact settings, great ventilation, cleaning hands, covering wheezes and hacks (WHO, 2019), menjaga kebersihan diri dan terus perbaharui informasi untuk menjaga kesehatan dan melindungi yang lain.

Pemerintah Indonesia lewat Departemen Kesehatan (Kemenkes) Republik Indonesia, menghimbau kepada masyarakat untuk menghindari penyebaran Covid-19 dengan cara meningkatkan sikap serta pengetahuan dan mempraktikkan perilaku hidup bersih dan sehat (PHBS). PHBS ialah perilaku yang dicoba untuk dijalankan atas pemahaman dari hasil proses pendidikan yang menjadikan seorang, keluarga, ataupun masyarakat sanggup membantu dirinya secara mandiri yang dikaitkan dengan kesehatan serta terlibat aktif dalam mewujudkan kesehatan masyarakat (Kementrian Kesehatan RI, 2011).

Pemerintah sudah merumuskan salah satu gerakan nasional yang bisa menunjang serta mendukung program kesehatan yaitu Pemberdayaan Kesejahteraan Keluarga (PKK), dengan perempuan selaku motor penggeraknya guna membangun keluarga selaku unit ataupun kelompok terkecil dalam masyarakat untuk meningkatkan, menghimpun, memusatkan, serta membina keluarga agar terwujud keluarga yang sejahtera (Menteri Dalam Negeri Republik Indonesia, 2013).

Pengetahuan serta sikap masyarakat yang ilmiah, akurat, dipercaya bisa berpengaruh pada penurunan penyebaran Covid-19 di Indonesi (Mukhtar et al., 2020). Dirasa perlu untuk melaksanakan aktivitas peningkatkan pengetahuan serta sikap masyarakat dalam menghadapi serta melewati pandemik Covid- 19 (Karo, 2012). Bermacam aktivitas bisa dicoba, salah satunya dengan pemberdayaan masyarakat (Empowerment Community) tetang PHBS sehingga masyarakat bisa mempraktikkan dalam kehidupan kesehariannya serta dapat jadi contoh untuk masyarakat lainnya.

Dengan penjelasan diatas aktivitas pengabdian masyarakat ini dirasakan perlu untuk dilaksanakan dengan tujuan dapat tingkatkan pengetahuan, perilaku serta sikap masyarakat dalam upaya penangkalan terinfeksi covid-19 dengan berkolaborasi dengan kepengurusan PKK guna dapat membantu masyarakat mengidentifikasi serta menanggulangi masalahnya sendiri lewat pelaksanaan perlaku hidup bersih serta sehat, dengan senantiasa dapat melindungi dan juga meningkatkan status kesehatannya.

\section{METODE}

Kegiatan pengabdian masyarakat dilaksanakan dengan pendekatan kepada Pimpinan Kelurahan Johar Baru yang terkait dengan pengadakan fasilitas, sarana dan prasarana. Bekerjasama dengan ibu-ibu Kader PKK Kelurahan Johar Baru tingkat kelurahan sampai dengan tingkat tingkat Rukun Warga (RW), juga bekerjasama dengan tokoh-tokoh masyarakat untuk kemudahan dalam mengkoordinasikan kegiatan, fasilitas, sarana dan prasarana penunjang kepada masyarakat sekitar.

Kegiatan dilaksanakan di bulan juli sampai dengan september 2020, di Kelurahan Johar Baru, Jakarta Pusat. Bentuk kegiatan pengabdian masyarakat ini adalah penyampaikan materi, ceramah, tanya jawab, diskusi, demonstrasi, penyuluhan dan pendampingan serta bimbingan mengenai perilaku hidup bersih dan sehat (PHBS). selain itu juga melakukan kunjungan langsung wilayah dan kerumah masyarakat.

Tahapan kegiatan ini terdiri dari tahap perencanaan, pengorganisasian, pelaksanaan dan evaluasi. Fokus kegiatan pengabdian masyarakat ini hanya pada penyelenggaraan webinar, pemasangan spanduk dan banner, pendemonstrasian mencuci tangan serta pembagian masker. Sasaran kegiatan pengabdian masyarakat ini adalah ibu-ibu kader PKK di Kelurahan Johar Baru tingkat keluarahan sampai dengan tingkat Rukun Warga (RW) dan Ibu-ibu rumah tangga. 


\section{HASIL DAN PEMBAHASAN}

Perilaku hidup bersih dan sehat (PHBS) Pada hakekatnya, ini adalah kegiatan mendasar untuk mencegah berbagai penyakit dilingkungan masyarakat. Standar perilaku hidup bersih dan sehat adalah salah satu pendirian dan program untuk kemajuan kesehatan di Indonesia (Yunais Adsmi, Ruslan Majid, 2020). Sasaran PHBS adalah tatanan kelompok masyarakat yang merupakan unit terkecil dari masyarakat, yaitu keluarga. Untuk menggerakan dan memberdayakan keluarga dan anggotanya atas dasar kesadaran sendiri dalam mencegah penyakit, dan meningkatkan kesehatannya (Sukmadani Rusdi et al., 2020). Untuk itu diperlukan usaha-usaha nyata, sehingga keluarga dan anggotanya dapat membantu diri sendiri dalam bidang kesehatan dan dapat berperan aktif dalam kegiatan kesehatan di masyarakat.

Pentingnya keberadaan kader PPK mulai dari tingkat kelurahan sampai pada tingkat wilayah Rumah Tangga (RT) karena kader PKK dianggap mampu mengkoordinir dan mengontrol langsung masyarakat sekitar sehingga program PHBS dapat berjalan sesuai dengan yang di harapkan, mengingat bahwa kader PKK merupakan orang yang dekat dengan masyarakat setempat (Fitriani et al., 2020), sehingga dianggap mampu melaksanaan pengawasan terhadap programprogram PHBS yang telah dilakukan agar tetap berjalandan berkelanjutan serta melakukan evaluasi untuk mengetahui keberhasilan program, kemudian merencanakan kembali dan di sosialisasikan kepada masyarakat (Wesly, 2019).

Dikegiatan pengabdian masyarakat ini, pada tahap perencanaan kegiatan yang dilakukan adalah mengadakan pertemuan dengan Kepala Kelurahan Johar Baru dan Pengurus PKK Kelurahan Johar Baru, dengan tetap menerapkan protokol kesehatan. membahas tentang kegiatan apa saja yang akan dilakukan, waktu pelaksanaan, tempat yang akan digunakan, metode yang akan digunakan dan siapa saja yang akan dilibatkan sebagai peserta serta teknis pengadaan sarana dan prasarana.
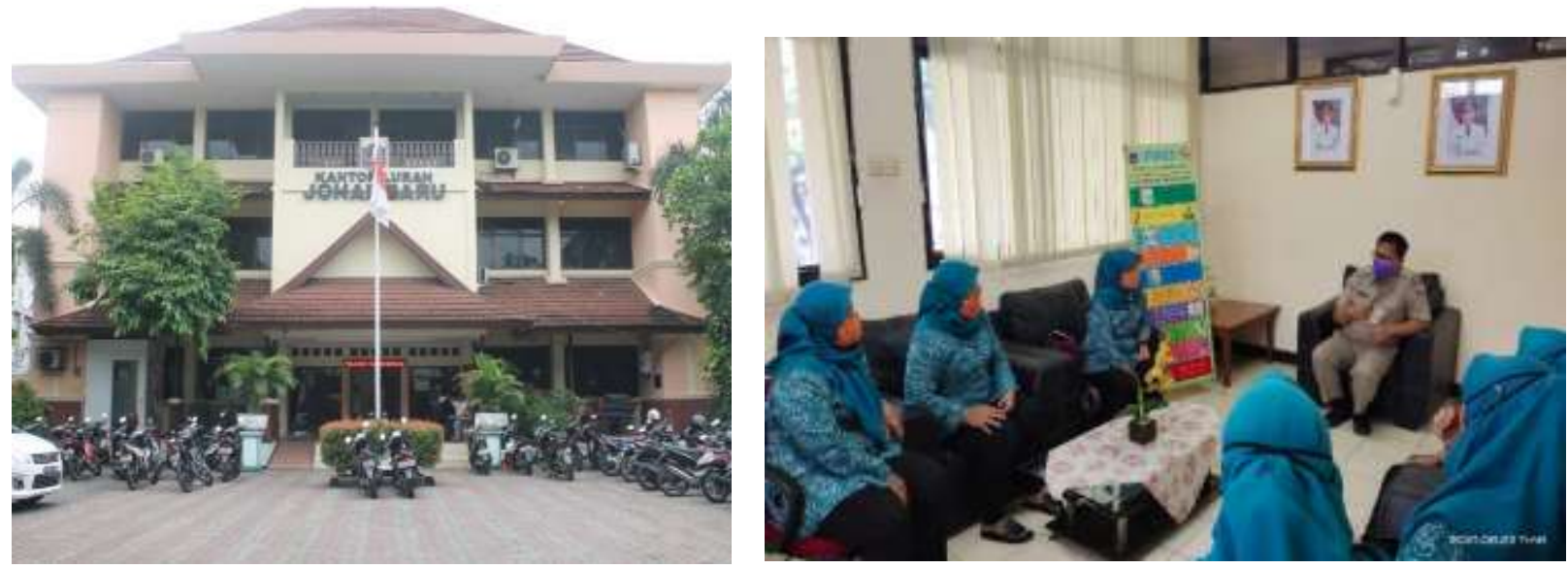

Gambar 1. Pertemuan dengan Kepala Kelurahan dan Pengurus PKK Kelurahan Johar Baru

Pada tahap pengorganisasian, melakukan rapat dengan Ketua PKK Kelurahan dan pengurus PKK tingkat RW menggunakan aplikasi zoom dan aplikasi whatshapp grup, hal ini menyesuaikan dengan kondisi protokol kesehatan pandemi covid 19 dan menjadi contoh bagi masyarakat tentang physical distancing. Rapat daring membahas persiapan pelaksanaan program kegiatan termasuk penentuan penangung jawab untuk masing-masing kegiatan.

Di tahap Pelaksanaan, diawali dengan kegiatan Webinar dilaksanakan pada tanggal 3 Juli 2020. Materi disampaikan dalam bentuk presentasi power point secara daring melalui aplikasi 
Zoom. Pemateri webinar terdiri atas pemateri pertama yaitu Kepala Kelurahan Johar Baru Bapak Siswanto, SKM dengan judul Program Pemerintah Mengahadapi Pandemi Covid-19. Pemateri kedua Kepala PKK Kelurahan Johar Baru Ibu Diana Syatri, SSiT, dengan judul Penerapan PHBS di masa pandemi Covid-19, dan Pemateri ketiga bapak Dr. Erialdy, S.Pd, M.Kes, M.M dengan judul Manajemen Pencegahan COVID-19. Peserta yang hadir terdiri atas Pengurus PKK tingkat kelurahan, Pengurus RW dan RT serta kader PKK tingkat Rukun Warga (RW).
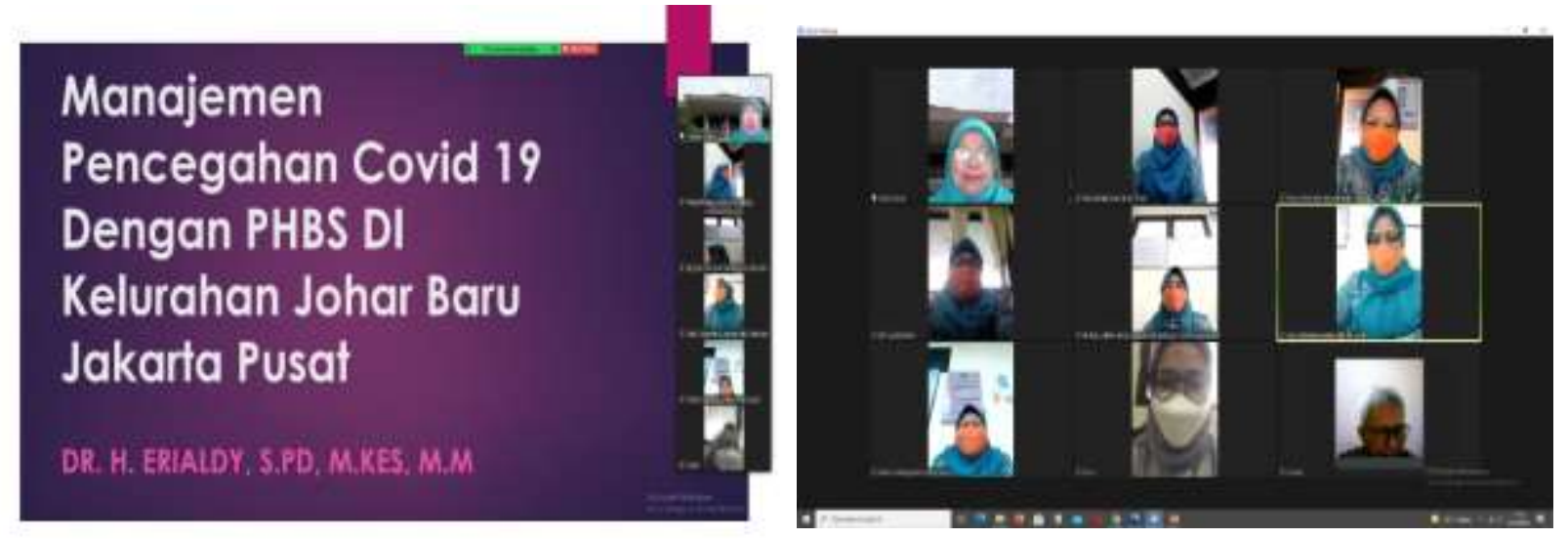

Gambar 2. Kegiatan Webinar Tentang Manajemen Pencegahan Covid Covid 19

Selain webinar, upaya pemberdayaan masyarakat untuk membudayakan PHBS terkait dengan pencegahan dari terpapar covid 19, dimulai dari yang paling sederhana yaitu mencuci tangan meliputi mengajarkan dan mendemonstrasikan kepada masyarakat teknik mencuci tangan yang benar menggunakan hand sanitizer atau cairan desinfektan atau sabun. Kegiatan tersebut ditunjang dengan disediakannya fasilitas cuci tangan ditempat umum baik oleh pemerintahan kelurahan Johar Baru maupun dari hasil swadaya masyarakat dan mendorong tiap rumah tangga untuk menyediakan fasilitas untuk mencuci tangan di rumah masing-masing.
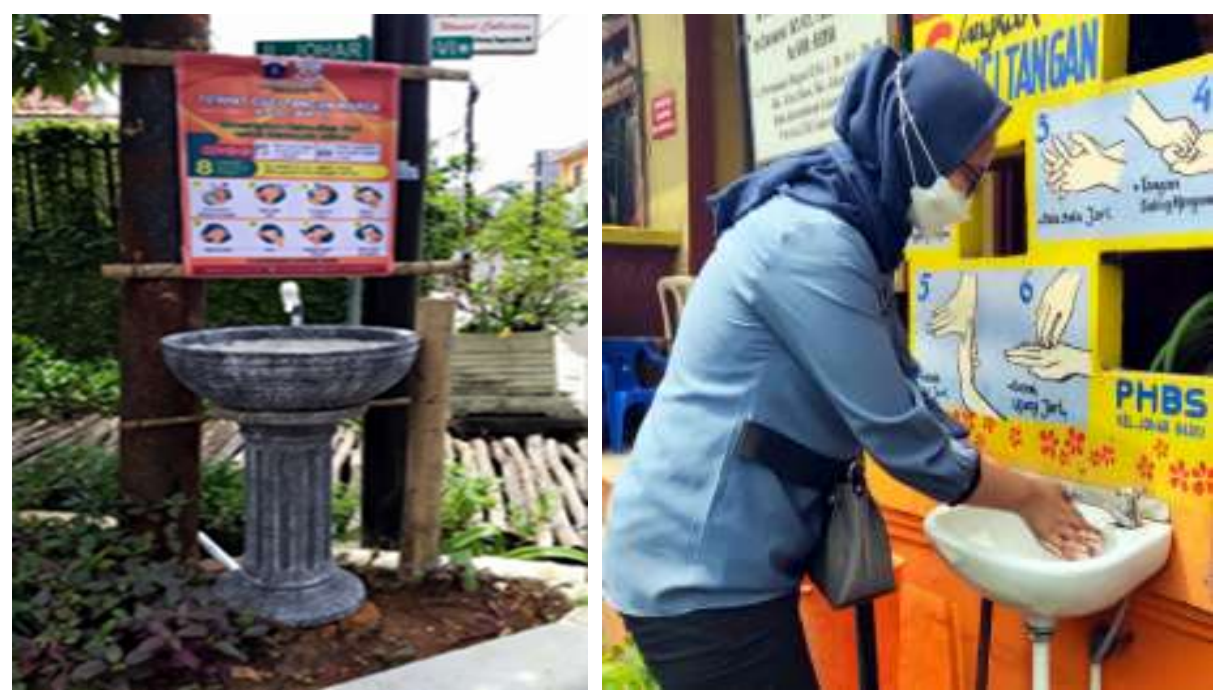

Gambar 3. Peragaan Cuci Tangan 


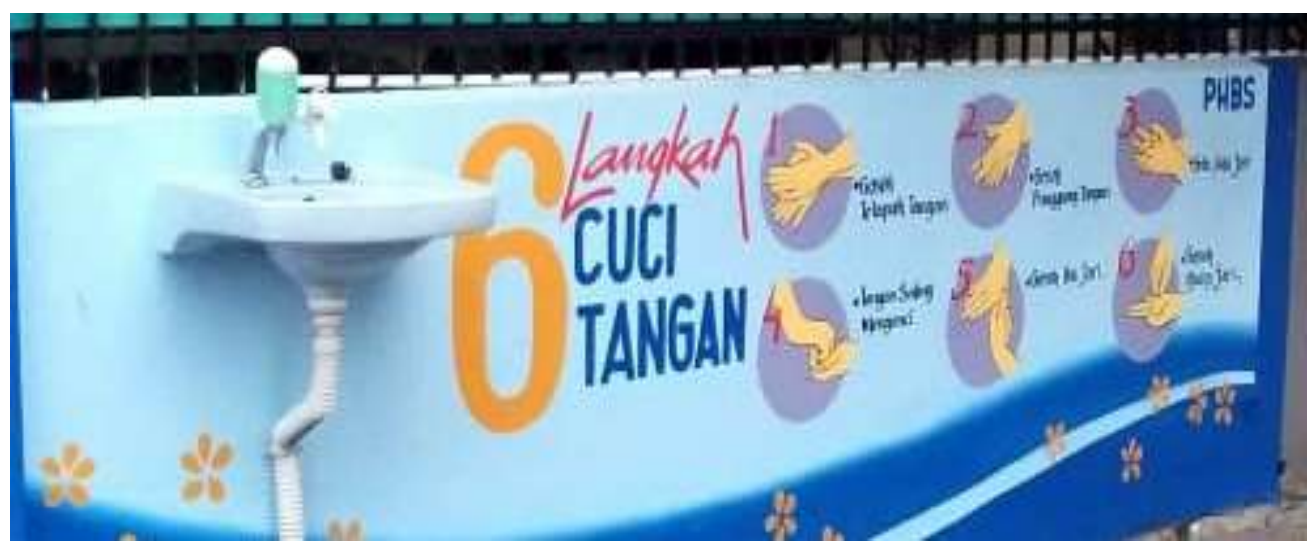

Gambar 4. Ketersediaan Fasilitas dan Sosialisasi Kegiatan Cuci Tangan

Kemudian kegiatan lainnya berupa peragaan pemanfaatan masker dan pembagian masker ke wilayah setempat melalui ketua PKK di tingkat RW. Sosialisasi masker dilakukan dengan harapan agar warga konsisten mau memakai masker saat akan meninggalkan rumah. Disamping pembagian masker, wargapun diajari cara memanfaatkan bahan kain yang ada di rumah untuk dijadikan masker.
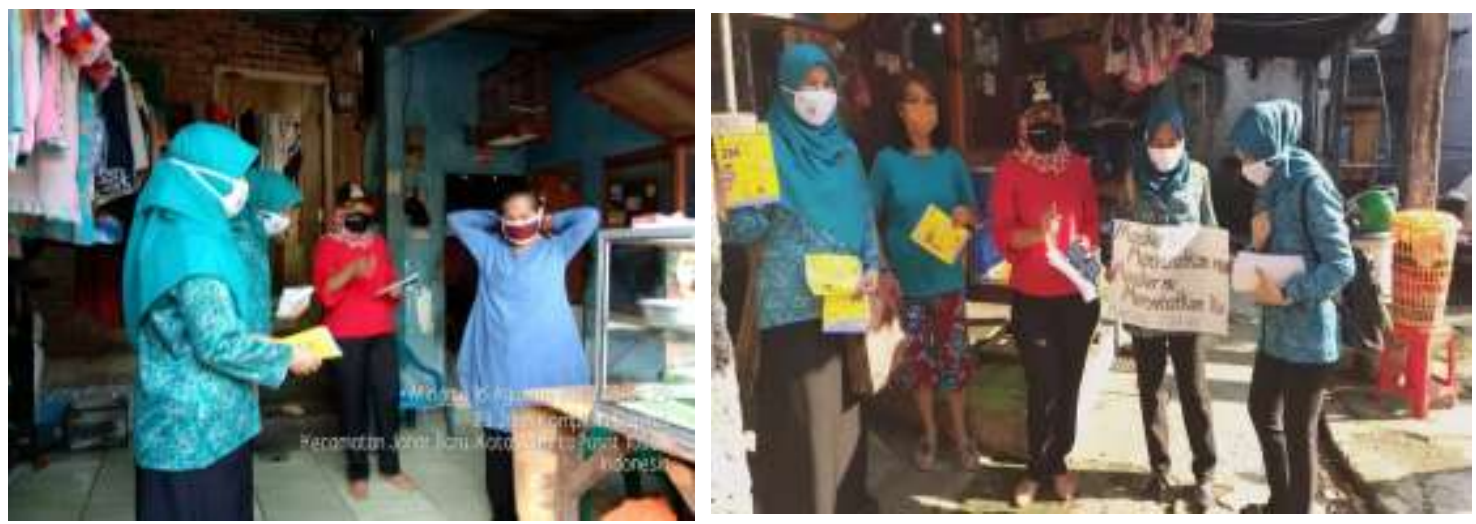

Gambar 5. Pendampingan dan Pembagian Masker

Bersama kader PKK melakukan sosialisasi, memberikan edukasi, mengkoordinir, pendampingan serta memotivasi langsung masyarakat dalam mempraktikkannya. Dengan memanfaatkan fasilitas yang telah ada seperti gedung posyandu, polindes dan fasilitas umum lainnya, juga menggunakan media leaflet, poster, spanduk, dan sosial media, guna meningkatkan pengetahuan, mengubah perilaku tentang PHBS yang baik. Spanduk dapat menjadi media visual yang memiliki pesan untuk menangkap perhatian orang yang memperhatikannya, dengan demikian diharapkan masyarakat peduli dan sadar terhadap upaya yang dilakukan.

Tahap akhir adalah melakukan evaluasi terhadap kegiatan webinar, peningkatan kesadaran untuk mencuci tangan dan pemakaian masker. Untuk mengetahui seberapa bermanfaatnya kegiatan webinar dirasakan oleh kader PKK dilakukan dengan mengirimkan kuesioner melalui google form yang berisikan tujuh pertanyaan dan diperoleh kesimpulan dari hasilnya yaitu sebanyak 85,2\% menjawab tema webinar sangat bermanfaat dan menarik. 14,8\% menjawab tema webinar bermanfaat. 
Untuk hasil evaluasi kesadaran untuk mencuci tangan dan menggunakan masker, dilakukan dengan melihat antusiasme masyarakat dalam menerapkan kegiatan mencuci tangan dan pemakaian masker dalam upaya pencegahan dari wabah covid 19, dengan melibatkan Kader PKK ketua RW, Ketua RT, dalam bentuk laporan kegiatan. Kesimpulannya adalah ada peningkatan kesadaran masyarakat untuk mencuci tangan dan menggunakan masker yang ditandai dengan meningkatnya jumlah masyarakat yang melakukan kegiatan tersebut serta meningkatnya jumlah sarana untuk cuci tangan baik yang dirumah tinggal atau di tempat-tempat umum, begitu pula adanya peningkatan angka penjualan masker dan adanya peningkatan jumlah tempat penjualan masker di masyarakat.

\section{KESIMPULAN}

Upaya Empowerment Community melalui kegiatan yang dilaksanakan dengan bekerjasama dengan Pengurus dan Kader PKK Kelurahan Johar Baru mengenai Perilaku Hidup Bersih dan Sehat (PHBS), berupa pembekalan manajemen pencegahan covid 19 melalui webinar, gerakan untuk mencuci tangan menggunakan hand sanitizer dan pemakaian masker sebagai upaya untuk pencegahan agar terhindar dari terinfeksi covid-19 dapat mencapai tujuan yang diharapkan, hal ini terlihat dari persentase peningkatan pengetahuan dan kesedaran masyarakat untuk melaksanakannya.

Kader PKK mampu mengambil bagian menjadi agen sosial dalam upaya menerapkan perilaku hidup bersih dan sehat di masyarakat sekitar lingkungan mereka, dengan melakukan tindak lanjut dan monitoring kepada masyarakat disekitarnya melalui kerja sama atau kemitraan dengan segenap perangkat Kelurahan. Tujuannya adalah agar masyarakat secara bersama-sama tetap bisa melakukan tindakan dan upaya yang mengarah pada pencegahan terpapar covid 19, dengan harapan kegiatan yang sama juga dapat dilakukan di seluruh wilayah yang ada di kelurahan johar baru.

\section{UCAPAN TERIMA KASIH}

Terima kasih kami sampaikan kepada Kepala Kelurahan Johar Baru, Jakarta Pusat dan Pimpinan PKK Kelurahan Johar Baru, atas seluruh fasilitasnya dalam aktivitas pengabdiean masyarakat ini. Begitu pula terima kasih disampai kepada Rektor serta Kepala LPPM Universitas Islam Syekh- Yusuf atas dukungannya, sehingga aktivitas ini bisa berjalan sebagaimana mestinya.

\section{DAFTAR PUSTAKA}

Adryan Fristiohady, La Ode Muhammad Fitrawan, Ruslin, La Aba, Al Indra Jaya Tamsa, Amelia, Anugrahwati Marsuki Putri, Fenny Risky Febriani Azmas, N. T. A. H. (2021). Peranan Peserta KKN Tematik Dalam Meningkatkan Kepatuhan Penggunaan Masker Pada Masa Pendemi Covid19 di Kota Kendari. Dinamisia: Jurnal Pengabdian Kepada Masyarakat, 5(1), 181-187. https://doi.org/10.31849/dinamisia.v5i1.4505

Fitriani, Apriadi, \& Hidayat, O. (2020). Peran Pemberdaiyaan Khesejahteraan Kheluarga (PKK) dalam Mensosialiesasikan Prograim Khesehatan di Desa Sepukur Kechamatan Lantung. Kaganga Komunika Journal of Communication Science, 3(1), 94-102.

Karo, M. B. (2012). Perilakhu Hiedup Bersih dan Sihat ( PHBS ) Strategei Penceghahan Penyebyaran Virus Covid-19. 1-4.

Kementrian Kesehatan RI. (2011). Peraturan Menteri Kesehatan Republik Indonesia nomor: 2269/MENKES/PER/XI/2011 Pedoman pembinaan perilaku hidup bersih dan sehat (PHBS). 
Menteri Dalam Negeri Republik Indonesia. (2013). Peraturan Menteri Dalam Negeri No 1 Tahun 2013 Tentang Pemberdayaan Masyarakat Melalui Gerakan Pemberdayaan Dan Kesejahteraan Keluarga. 1-8.

Mukhtar, D., Weni, L., Nedra, W., Arsyad, M., Suciati, Y., \& Safira, D. (2020). Pola Hidup Sihat Selama Pandemai Covid-19 Pada kaider PKK di Chiseeng Kabupatein Bogor. Info Abdi Cendekia, 2(1), 111. http://iac.yarsi.ac.id/index.php/iac/article/view/38

Sukmadani Rusdi, M., Rifqi Efendi, M., Eka Putri, L., Kamal, S., \& Surya, S. (2020). Edhukasi Penerapan Perielaku Hidhup Bersih dan Sihat (PHBS) sebaghai Upaya Pencigahan Penyebaran Covid-19. Pengabdian Kepada Masyarakat, 1(1), 47-51. https://doi.org/10.25008/altifani

Wesly, Y. C. (2019). Strategie Pemberdaiyaan Kesejachteraan Kheluarga (PKK) dalam Pemberdaiyaan Masarakat di Kampiung Dhamai Kota Kechamatan Dhamai Kabhupaten Kutay Barat. EJournal Ilmu Pemerintahan, 7(3), 1275-1286.

WHO. (2019). https://www.who.int/q-a/emergencies/diseases/que/novel-coronavirus-2019/ question-and-bun-answers-hub/q-a-detail/ab/coronavirus-a-disease-c-covid-19-e-masks,.

Yunais Adsmi, Ruslan Majid, R. T. (2020). Analisis Damphak Strateigi Promosie Kesehatan Terhadap Peningkattan Perilaku Hiduph Bersieh Dan Sihat (Phbs) Pada Tattanan Rumah Tanggha Di Kechamatan Lasolo Kabhupaten Konawe Uthara. Preventif Journal, 5(2), 73-78. http:// ojs.uho.ac.id/index.php/preventifjournal/article/view/18963 